\title{
Cruzando a órbita prum novo mar:
}

\section{Xênia França e o afrofuturismo no videoclipe de Nave}

\section{Crossing the orbit into a new sea:}

\section{Xênia França and the Afrofuturism in Nave's music video}

\section{Rafael Pinto Ferreira de Queiroz}

Doutor em Comunicação pela UFPE. Universidade Federal de Pernambuco, Programa de Pós-Graduação em Comunicação, Recife (PE), Brasil.

Xênia França nasceu em Candeias e foi criada em Camaçari, cidades do interior baiano. Em 2004 foi para São Paulo, então com 18 anos, para tentar a carreira de modelo, profissão que seguiu até 2008, quando começou a flertar com a música. De reuniões com rodas de violão em seu apartamento, onde fora incentivada a começar a cantar, passou a se apresentar em bares e conheceu Emicida, que a convidou para gravar em seu EP Sua Mina Ouve Meu Rep Também e no álbum Emicídio, ambos de 2010. A partir daí passou a receber cada vez mais convites para participar em feats de artistas do rap nacional e, no ano subsequente, passou a integrar a banda Aláfia, com a qual gravou três álbuns.

Em 2017, lançou seu primeiro disco solo, Xenia, em que assina três composições - uma delas em parceria com Lucas Cirillo - e reinterpreta outros autores. O disco apresenta afrossonoridades de um R\&B jazzy futurístico com beats, piano elétrico e sintetizadores combinados com as batidas ancestrais do rum, rumpi e le, os atabaques usados nos xirês - ritual/dança circular para evocar os orixás - do candomblé. Entre as músicas do álbum, está Nave, canção que fora escolhida para ser um dos singles e que se tornou videoclipe. Já sendo uma entusiasta do movimento artístico negro transnacional - o afrofuturismo, com 
suas escolhas estéticas visuais e musicais -, o videoclipe vem para consolidar esse lugar reivindicado pela artista. Há um certo sentido de ligação do passado ancestral com o futuro ficcional num sentido utópico, que está sendo antagonizado por um presente distópico, do qual voltaremos a falar mais adiante, sendo importante ir entrecortando a narrativa da cantora baiana com conceitos pensados acerca do afrofuturismo.

O termo foi criado em 1994 pelo crítico cultural Mark Dery, no famoso texto Black to the Future, em que entrevista autores negros sobre a relação da ficção científica com a negritude: o escritor Samuel R. Delany, o crítico cultural Greg Tate e a pesquisadora e professora Tricia Rose. Para o autor, o termo versaria sobre

Ficção especulativa que trata de temas afro-americanos e aborda as preocupações afro-americanas no contexto da tecnocultura do século $X X-$ e, de maneira mais geral, a significação afro-americana que apropria imagens de tecnologia e um futuro proteticamente melhorado - poderia, por falta de um termo melhor, ser chamada de "Afrofuturismo". (DERY, 1994, p. 180, tradução minha) ${ }^{1}$

A definição já foi devidamente ampliada por atravessar e se expandir ao século XXI e estar presente em expressões artísticas da diáspora e do continente africano, não apenas nos EUA. Xênia é tida como uma das representantes no Brasil dessa forma cultural e, talvez, em um videoclipe anterior, Pra que me chamas?, já dê algumas pistas dessa tendência. Ali, seu vestido vermelho evoca lansã, mas seu estilo nos remete ao futurismo, enquanto a misteriosa luz que emana da boca das personagens pode indicar o que Dery (1994) define como "tecnologia do sagrado", um termo que toma emprestado de Jerome Rothenberg. Na ocasião, Greg Tate afirma que muitas expressões artísticas visuais negras remetem a uma “paisagem visionária" (p. 209-210, tradução minha):

Portanto, se você observar o trabalho de artistas visuais negros, de grafiteiros a Jean-Michel Basquiat, sempre haverá essa inserção de figuras negras em uma paisagem visionária, se não uma ficção científica ou uma paisagem de fantasia. $O$ salto imaginativo que associamos à ficção científica, em termos de colocar o humano em um ambiente alienígena e alienante, é um gesto que aparece repetidamente no trabalho de escritores negros e artistas visuais. ${ }^{2}$

\footnotetext{
1 No original: "Speculative fiction that treats African-American themes and addresses African-American concerns in the context of twentieth century technoculture-and, more generally, African-American signification that appropriates images of technology and a prosthetically enhanced future-might, for want of a better term, be called "Afrofuturism."

2 No original: "So if you look at the work of black visual artists, from graffiti artists to Jean-Michel Basquiat, there is always this insertion of black figures into a visionary landscape, if not a science fiction or fantasy landscape. The imaginative leap that we associate with science fiction, in terms of putting the human into an alien and alienating environment, is a gesture that repeatedly appears in the work of black writers and visual artists."
} 
Tate amplia esse salto imaginativo comentado através da obra de Ishmael Reed, outro escritor afrofuturista, indicando que esse impulso já estaria presente na espiritualidade afrodiaspórica, como no vodu, na macumba e santeria. Assim, Dery (1994, p. 210, tradução minha) faz uma conexão sugestiva de tecnologia com ancestralidade, colocando artefatos dos ritos de matriz africana como meios de manipular uma realidade virtual:

Vale ressaltar, no contexto do que escolhi chamar de "Afrofuturismo", que os talismãs e o pó mágico do Delta blues, juntamente com os amuletos da sorte, fetiches, efígies e outros dispositivos empregados em sistemas de crenças sincréticas, como vodu, hoodoo, santeria, mambo e macumba, funcionam de maneira semelhante aos joysticks, Datagloves [luvas virtuais], Waldos e Spaceballs usados para controlar realidades virtuais. Jerome Rothenberg os chamaria de tecnologias do sagrado. ${ }^{3}$

Certas imagéticas e filosofias engendradas pelo afrofuturismo estariam então já presentes no imaginário criado por negros e negras desde muito tempo, como viagens espaciais e encontros alienígenas. A própria experiência traumatizante da escravidão já teria sido a de uma abdução alienígena, em que africanos foram levados a uma terra estranha, de condição alienante, onde todos os traços de cultura, costumes, histórias, nomes, línguas e relações familiares foram forçosa e intencionalmente erradicados.

Xênia França expande a iconografia afrofuturista no videoclipe da canção Nave, do mesmo álbum Xenia (2017), mas lançado em 2019. O clipe foi dirigido pelo duo DIABA (Camila Maluhy e Octávio Tavares) e teve argumento e roteiro de ambos e de Xênia. Com estética sci-fi, o vídeo narra a história da personagem Xaniqua, uma astronauta solitária que vaga pelo universo em busca de formas de vida. A cantora afirma que a personagem foi inspirada em Mae Carol Jemison, primeira negra a ir ao espaço, e a escolha se deu porque, apesar de já ser um fato concreto, mulheres negras raramente são representadas dessa maneira na cultura pop. ${ }^{4}$ Curioso pensar que a própria Jemison comenta que uma das suas inspirações para virar astronauta foi a personagem tenente Uhura, da série de Sci-fi Jornada nas Estrelas, interpretada pela atriz afro-americana Nichelle Nichols.

A canção, de Clarice Peluso e Veronica Ferriani, fala sobre desentendimentos e falta de vínculos que geram ódio, julgamentos, linchamentos e perseguições e que têm acontecido e aumentado no mundo das

3 No original: "It's worth pointing out, in the context of what I've chosen to call "Afrofuturism," that the mojos and goofer dust of Delta blues, together with the lucky charms, fetishes, effigies, and other devices employed in syncretic belief systems, such as voodoo, hoodoo, santeria, mambo, and macumba, function very much like the joysticks, Datagloves, Waldos, and Spaceballs used to control virtual realities. Jerome Rothenberg would call them technologies of the sacred."

4 DENISE, Flávia. Xenia França parte em uma jornada de autoconhecimento no videoclipe de "Nave". OPovo, 21/03/2019. Disponível em: <https://orbezero.com.br/xenia-franca-parte-em-uma-jornada-de-autoconhecimentono-videoclipe-de-nave/>. Acesso em: 04/05/2020. 
redes sociais. Diante disso, sair do planeta Terra seria uma solução, fazendo uma viagem espacial para encontrar um lugar onde "só vai crescer amor". Pensando na insatisfação dessa vida na terra, por meio de Xênia e sua música, pode-se fazer um paralelo com a situação das populações negras e a hostilidade do racismo, fazendo de viagens interplanetárias um imaginário que se liga a fugir desse sofrimento. $\mathrm{O}$ refrão diz:

Pode chegar / Quando chispar a nave eu vou / Cruzar a órbita prum novo mar / Que a nossa lua transbordou / Vazou

Pode correr / Que lá só vai crescer amor / Ó minha mãe, perdoa se eu te deixar / Que esse planeta é gente demais

Na versão do clipe de Xênia, a música começa com a captação de diferentes frequências de rádio enquanto aparecem imagens do espaço. Ouvimos a marcação de notas graves de um teclado ou sintetizador, que é acompanhado de sons que lembram o de um sonar, trazendo um clima de mistério e uma atmosfera sci-fi. Depois disso, podemos ouvir a voz de Xênia, e outras sonoridades são acrescentadas com o sintetizador, ajudando a criar uma narrativa futurista, até chegar ao refrão, em que sua entrada é marcada por percussão semelhante aos samba-reggaes baianos. A essa percussão, é adicionada uma guitarra distorcida e outros sons "tecnológicos" que, ao mesmo tempo que reforçam a citação à ficção científica, transmitem uma ideia de ruído de comunicação e caos, algo que se conecta ao sentimento da letra.

Nave (2019), ao trazer uma narrativa de ficção científica, de viagens espaciais, está refletindo o estranhamento e a sensação de deslocamento comuns às subjetividades afrodiaspóricas. Essa alienação leva Eshun (2003, p. 298, tradução minha) a afirmar que "existência negra e ficção científica são uma e a mesma coisa" ${ }^{5}$. Alienação, deslocamento e estranhamento, lembra o mesmo autor, já tinham sido teorizados por Du Bois e sua dupla consciência desde As almas da gente negra, lançado em 1903.

Interessante fazer a ligação com o que Ytasha Womack (2013, p. 140-142) destaca, pois o próprio Du Bois também chegou a escrever fiç̧ão científica - a história curta The Comet, presente no livro Darkwater (1920). A autora escreve que ele foi um dos muitos ativistas que, a partir do século XIX, fizeram uso do sci-fi ou da ficção especulativa para "discutir ideias sobre raça, recriar futuros com sociedades

\footnotetext{
${ }^{5}$ No original: "black existence and science fiction are one and the same"
} 
negras, e fazer comentários mordazes sobre os tempos" (p. 120, tradução minha) ${ }^{6}$. Ela cita vários outros autores e uma autora que seguiram esse modo de escrever, e, entre os mais famosos, está Martin Delany, importante abolicionista e um dos precursores das ideias do nacionalismo negro.

A arte afrodiaspórica, sendo feita a partir de um sujeito em luta com estruturas de poder, que usa suas desvantagens psicossociais como uma vantagem narrativa, pode encorajar processos de desalienação (ESHUN, 2003, p. 298). Já colocamos que a metáfora da extraterritorialidade é usada como parte de sentimento de deslocamento e abdução: os europeus foram os ETs que abduziram os africanos ao terem suas terras invadidas por navios, as naves - navio ou nau têm estreita relação semântica com nave. Aqui sofreram várias experiências "científicas" em seus corpos: o estupro que gerou miscigenação, as amputações, linchamentos, chicotadas, técnicas de tortura que eram aplicadas e testadas como limites máximos de nossos corpos. E elas continuaram com a medição de nossos crânios, a esterilização forçada de mulheres negras - práticas a serviço da eugenia — , as armas, os drones e helicópteros que atiram para nos matar.

Esse pesadelo sci-fi é muito real, e metáforas com o espaço e a distância podem servir como reflexos dessa realidade: "Deve ser entendido não tanto como escapismo, mas como uma identificação com a potencialidade do espaço e da distância dentro da zona de alta pressão da perpétua hostilidade racial” (p. 299, tradução minha). ${ }^{7}$ Dessa forma, Xênia França, em Nave, utiliza-se de elementos da ficção científica para espelhar um descontentamento e um sentimento de não pertença que se carrega desde a abdução/alienação da escravidão.

As roupas, os dispositivos eletrônicos, os materiais de laboratório remetem a uma tecnocultura futurística, ao mesmo tempo que símbolos que remetem aos hieróglifos egípcios (Medu Neter) e aos búzios do candomblé ligam o passado ao futuro, como se já fossem tecnologias avançadas.

\footnotetext{
${ }^{6}$ No original: "[...] used speculative fiction and sci-fi to hash out ideas about race, re-create futures with black societies, and make poignant commentary about the times".

7 No original: "It should be understood not so much as escapism, but rather as an identification with the potentiality of space and distance within the high-pressure zone of perpetual racial hostility."
} 


\section{ALCEU}

Figura 1 - "Medu Neter" - Nave (2019); Fonte: YouTube

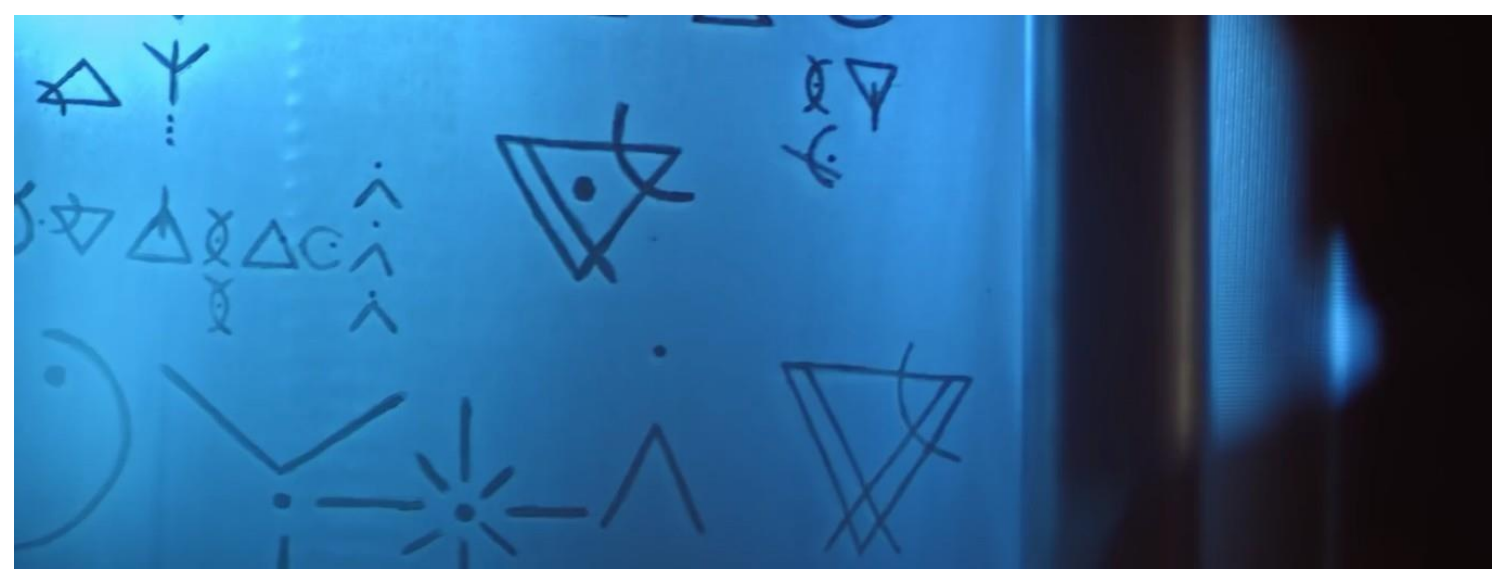

Figura 2 - Búzios - Nave (2019); Fonte: YouTube

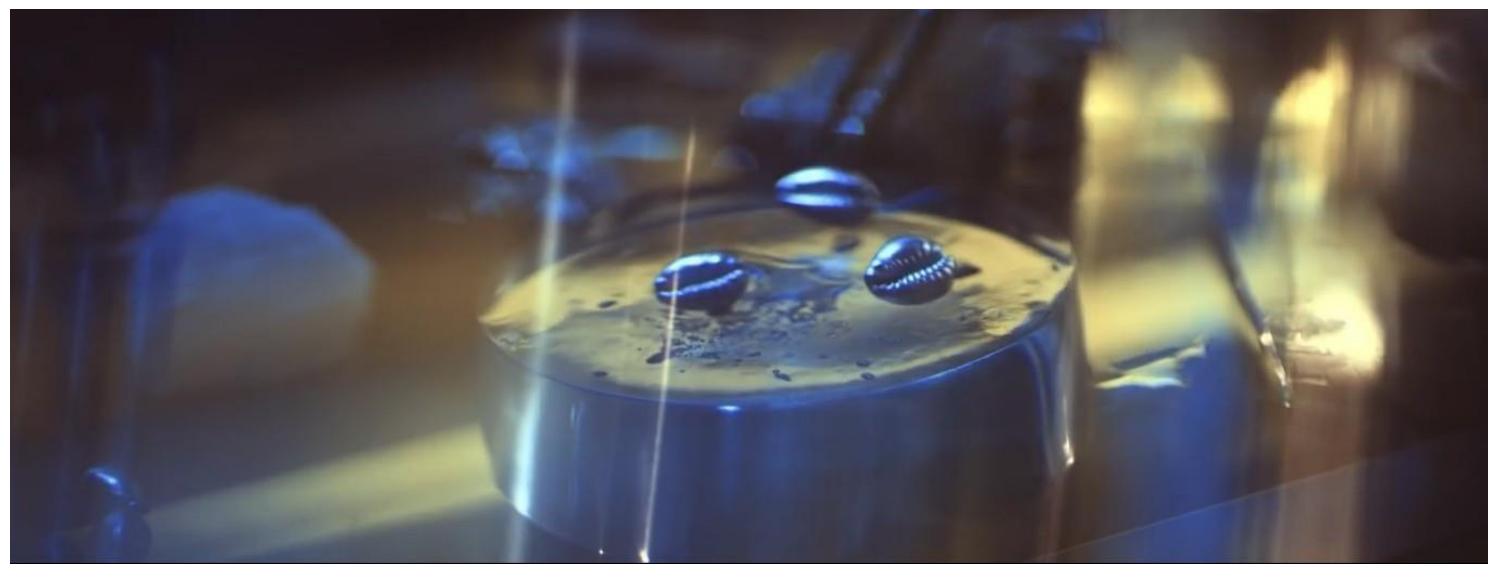

Figura 3 - Laboratório - Nave (2019); Fonte: YouTube

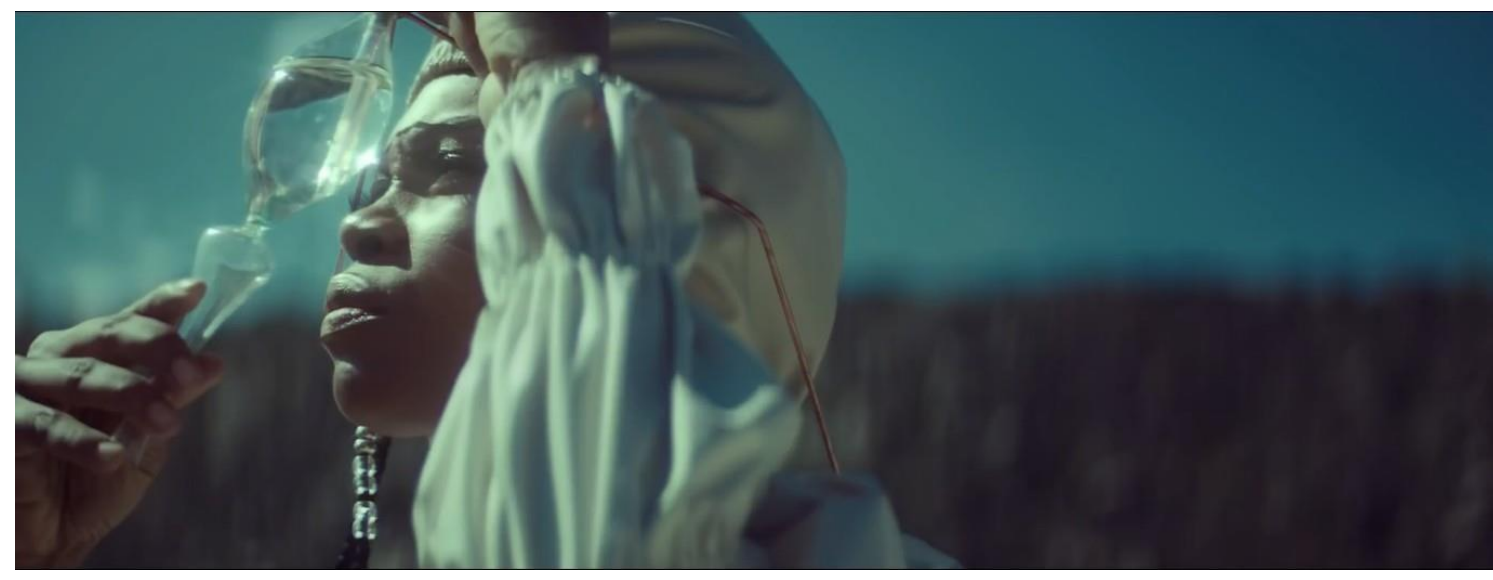


Na entrevista conduzida por Mark Dery (1994, p. 210), Greg Tate afirma que o impulso do salto imaginativo presente em afrofuturismos é encontrado desde o Kemet:

\begin{abstract}
Vejo a ficção científica como uma linha de investigação filosófica e especulação tecnológica que começa com os egípcios e suas meditações incrivelmente detalhadas sobre a vida após a morte. FC representa um tipo de codificação racionalista, positivista e científica desse impulso, mas ainda é proveniente de um desejo humano básico de conhecer o incognoscível, e, para muitos escritores negros, esse desejo de conhecer o incognoscível se direciona para o autoconhecimento. Conhecer-se como uma pessoa negra - histórica, espiritual e culturalmente - não é algo que lhe é dado institucionalmente; é uma jornada árdua que deve ser realizada pelo indivíduo. ${ }^{8}$
\end{abstract}

Para Eshun (2003, p. 296), o afrofuturismo também é um resultado e até mesmo parte direta de movimentos sociais e de libertação. O autor cita como exemplos desde "movimentos político-espirituais", como a Escatologia Cristã Negra e o Black Power, até "tradições político-exotéricas", em que ele inclui a Nação do Islã, a Egiptologia, a cosmologia Dogon e as teses do Stolen Legacy (Legado Roubado):

A escatologia da Nação do Islã combinou um relato racializado de origem humana com uma teoria catastrófica do tempo. Ogotomelli, o místico Dogon, forneceu um conhecimento astronômico da Estrela do Cão "Sirius B", elaborada pelos etnógrafos franceses Marcel Griaule e Germaine Dieterlen, que demonstraram um conhecimento científico africano compensatório e superior. O desejo da Egiptologia de recuperar as glórias perdidas de um passado africano pré-industrial foi animado por um autoritarismo utópico. Antes de Black Athena de Martin Bernal (1988), o Stolen Legacy de George G.M. James (1989) enfatizou simultaneamente as conspirações brancas que encobriam o legado roubado da ciência africana, revertendo o pensamento hegeliano ao insistir na civilização africana original. (p. 296-297, tradução minha) ${ }^{9}$

Referências ao Egito Antigo, elaborações místicas e religiosas, assim como naves espaciais, viagens interplanetárias e miradas ao futuro, também aparecem na música negra brasileira em seus mais celebrados expoentes, como Gilberto Gil, Jorge Ben e Tim Maia. Talvez um dos primeiros álbuns com temática afrofuturista no Brasil seja o Gilberto Gil (1969), também conhecido como Cérebro Eletrônico, inclusive uma referência que está na letra de Nave. O disco tem uma capa com o desenho de um papiro

\footnotetext{
8 No original: "I see science fiction as continuing a vein of philosophical inquiry and technological speculation that begins with the Egyptians and their incredibly detailed meditations on life after death. SF represents a kind of rationalist, positivist, scientific codification of that impulse, but it's still coming from a basic human desire to know the unknowable, and for a lot of black writers, that desire to know the unknowable directs itself toward selfknowledge. Knowing yourself as a black person historically, spiritually, and culturally-is not something that's given to you, institutionally; it's an arduous journey that must be undertaken by the individual."

9 No original: "The Nation of Islam's eschatology combined a racialized account of human origin with a catastrophic theory of time. Ogotomelli, the Dogon mystic, provided an astronomical knowledge of the "Sirius B" Dog Star, elaborated by French ethnographers Marcel Griaule and Germaine Dieterlen, that demonstrated a compensatory and superior African scientific knowledge. Egyptology's desire to recover the lost glories of a preindustrial African past was animated by a utopian authoritarianism. Before Martin Bernal's Black Athena (1988), George G. M. James's Stolen Legacy (1989) simultaneously emphasised the white conspiracies that covered up the stolen legacy of African science, reversing Hegelian thought by insisting upon the original African civilization."
} 


\section{ALCEU}

ISSN: $2175-7402$

contendo um texto e desenhos enigmáticos. Muitas músicas, a maioria do próprio Gil, contêm letras de ficção científica, futuro e relação homem/máquina, potencializadas pelos arranjos futurísticos de Rogério Duprat: a já comentada Cérebro eletrônico que abre o disco, $A$ voz do vivo (Caetano Veloso), seguida de Vitrines, 2001 (Rita Lee e Tom Zé), Futurível e a altamente experimental Objeto semi-identificado (em parceria com Duprat e Rogério Duarte).

Figura 4 - Capas dos discos Gilberto Gil (1969) e Gilberto Gil e Jorge Ben - Ogum Xangô (1975); Fonte: Google Imagens
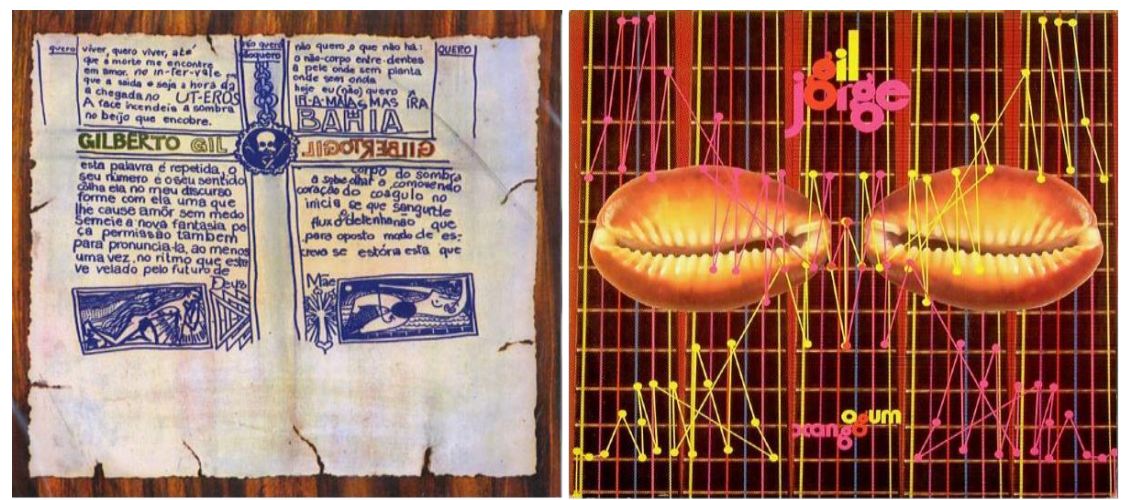

Outro importante artista a desenvolver essas temáticas é Jorge Ben. Junto com Gil criou o álbum de música experimental Gil e Jorge: Ogum - Xangô (1975). No disco falam de candomblé, de santo católico que também é venerado na umbanda, de um monumento indiano, entre outras coisas. O que fica mais latente é o sentido de experimentação do disco que, como veremos mais adiante, Corbett (1994) associa à exploração do desconhecido. Na capa, apresentam búzios em um desenho futurista, parecendo também uma tecnologia do sagrado, como vemos no videoclipe de Xênia. Um ano antes, Ben também já antecipava essa questão místico-espacial com seu álbum Tábua de Esmeralda (1974), falando de uma narrativa meio espacial, esotérica e tecnológica, com a alquimia como tema, que fora desenvolvida pelo faraó egípcio Hermes Trismegisto, como explica no encarte. Ele ainda faz música para outros alquimistas como Flamel e Paracelso e pergunta se os deuses na verdade não seriam astronautas de outras galáxias, baseado no livro de Erich von Däniken Eram os deuses astronautas? ${ }^{10}$.

\footnotetext{
${ }^{10}$ Há muitas teorias da conspiração e ufólogos que perpetuam a visão racista de que teria sido impossível povos originários da África e das Américas terem construído civilizações tão grandiosas e tecnologicamente avançadas, sendo atribuída a esses feitos a possibilidade de encontros com alienígenas que os ensinaram ao trazerem seus conhecimentos. Isso é comentado pelo astrônomo Neil Degrasse Tyson no programa de rádio de Sway Calloway: https://www.youtube.com/watch?v=ZetaeaEvNkI
} 
Figura 5 - Capas dos discos de 1974: Jorgen Ben - A tábua de esmeralda; e TimMaia - Racional; Fonte: Google Imagens

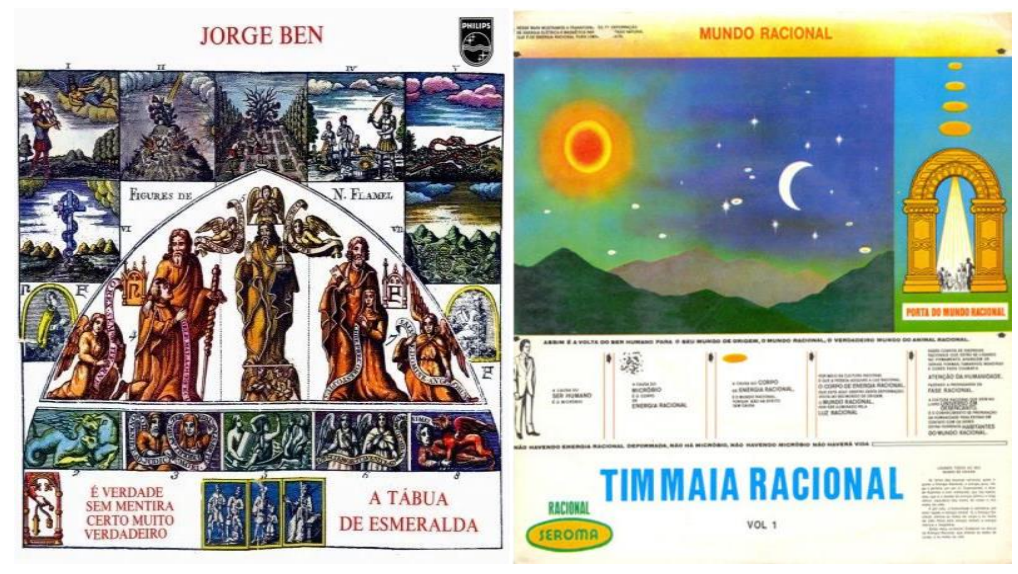

Nessa linha especulativa sobre o afrofuturismo musical brasileiro - já que foi a música que ajudou a consolidar essa estética negra, a partir do jazzista Sun Ra, como veremos - , não poderíamos deixar de citar outro disco, também de 1974, o Racional de Tim Maia. Ele havia entrado na seita Universo em Desencanto ou Cultura Racional, que fora criada por Manuel Jacinto Coelho, um negro que também fora músico e falava abundantemente sobre vida em outros planetas, viagens espaciais e em atingir a fase racional para poder sair do planeta Terra e viver plenamente no Mundo Racional: fortes elementos de ficção científica e misticismo, como Eshun (2003) havia identificado em influenciadores do afrofuturismo. Aqui o paralelo é musical, na música negra brasileira, sem enfatizar o conteúdo político, histórico e social que o autor conecta, mas levantando a possibilidade de o binômio experiência negra/fiç̧ão científica ser algo identificável para além das cercanias afro-americanas.

Eshun (2003, p. 297, tradução minha) continua sua análise sobre ligações entre movimentos raciais, religião e teorias sobre a recuperação histórica de um passado africano científico-tecnológico ao mesmo tempo que antecipa que o Afrofuturismo e seus antecedentes não são "inocentemente celebrativos". Essas "futurologias vernaculares", diz, são outras formas de interpretar o mundo que desafiam as visões dominantes estabelecidas e assim produzem um distúrbio temporal na narrativa dos vencedores.

Ao criar complicações temporais e episódios anacrônicos que perturbam o tempo linear do progresso, esses futurismos ajustam a lógica temporal que condenou os negros à pré-história. Cronopoliticamente, essas historicidades revisionistas podem ser entendidas como uma série de futuros concorrentes poderosos que se infiltram no presente em diferentes graus. ${ }^{11}$

11 By creating temporal complications and anachronistic episodes that disturb the linear time of progress, these futurisms adjust the temporal logics that condemned black subjects to prehistory. Chronopolitically speaking, these revisionist historicities may be understood as a series of powerful competing futures that infiltrate the present at different rates. 
O autor ainda sustenta a tese de que essa qualidade revisionista está presente também em outras esferas da cultura negra, como na música e em intelectuais contemporâneos. Fá-lo ao lembrar que, na entrevista concedida a Paul Gilroy, a escritora Toni Morrison destrói a concepção padrão de modernidade, normalmente ligada à filosofia e ao conhecimento e desarticulada de noções como brutalidade e violência. Ao construir o binômio escravidão/modernidade e colocar que aqueles que sofreram experiências de "captura, roubo, abdução e mutilação" foram os primeiros modernos, a autora também provoca rupturas na narrativa espaço-temporal dominante.

Essa ruptura na linearidade espaço-temporal ocidental está presente na missão espacial narrada em Nave. Lá, Xaniqua analisa a terra, minerais e líquidos procurando vestígios que metaforizem a busca de conhecimentos. Na verdade, a viajante espacial negra está buscando autoconhecimento, buscando um passado, uma origem, uma ancestralidade que possa explicar de onde veio e reestruturar um Ser a partir de uma centralidade negra. Primeiramente ela faz uma escavação e encontra um fóssil de uma planta, que demonstra um avanço em sua pesquisa. Continuando sua busca no planeta que tem uma geografia quase desértica, uma aridez distópica, sem traço de fertilidade, vida ou abundância, Xaniqua usa o dispositivo tecnosacro do búzio, equipado com uma luz infravermelha em sua ponta, que havia sido enterrado no solo e agora indica uma descoberta. Na cena posterior, um cristal de tons lilases tem uma presilha dourada, e, como um fone bluetooth, Xaniqua o coloca no ouvido.

Figura 6 - Deserto Distópico - Nave (2019); Fonte YouTube

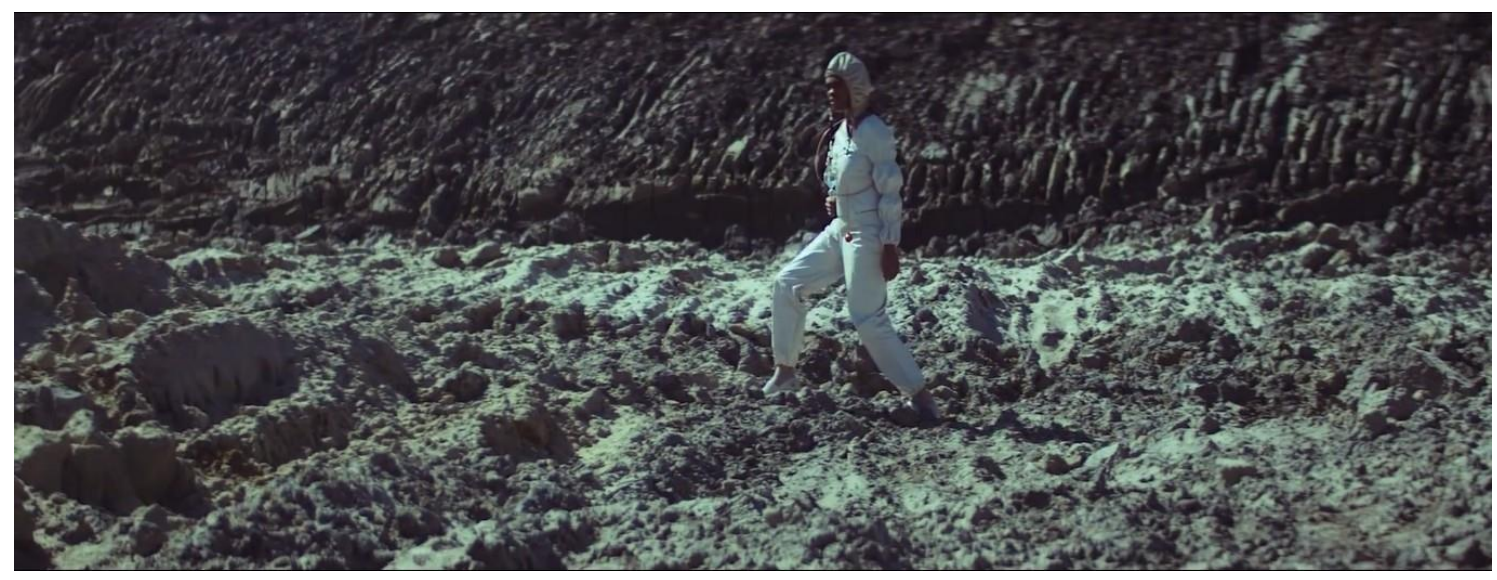




\section{ALCEU}

ISSN: 2175-7402

Figura 7 - Tecno-fóssil - Nave (2019); Fonte: YouTube

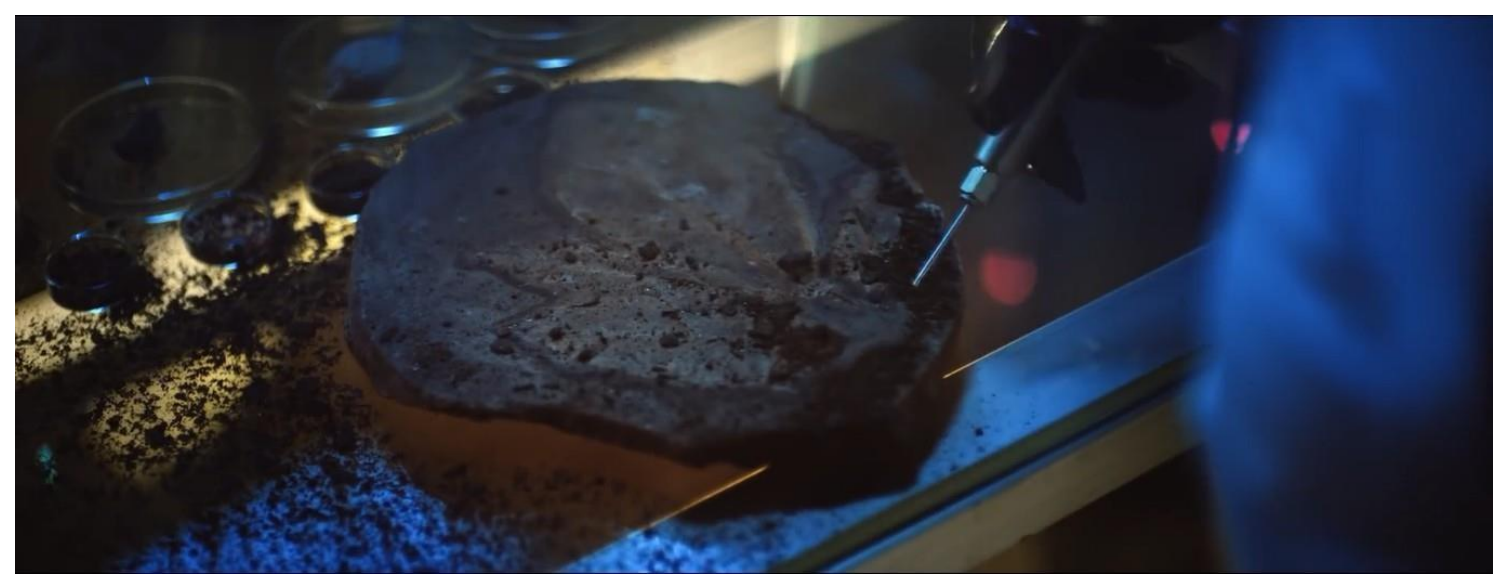

Figura 8 - Tecnologias do Sagrado - Nave (2019); Fonte: YouTube

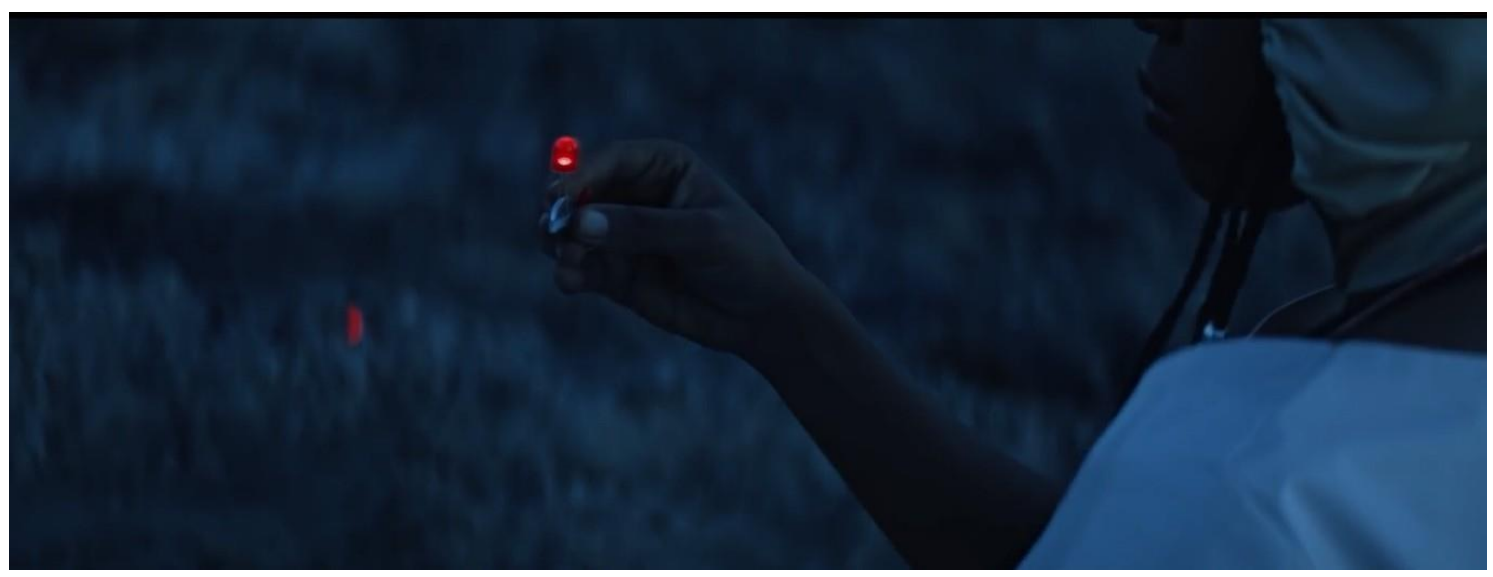

Figura 9 - Bluetooth - Nave (2019); Fonte: YouTube

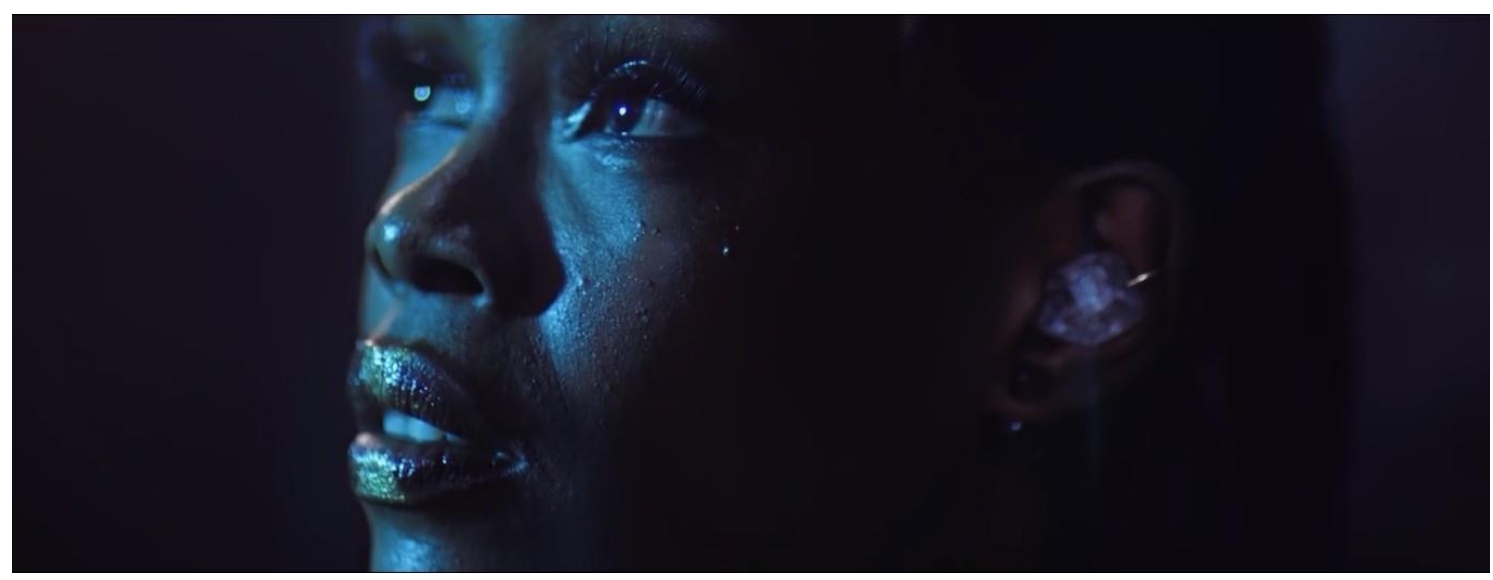




\section{ALCEU}

ISSN: $2175-7402$

Nesse momento, a música para, e ela começa a ouvir os sons de tambores e sons ambientes de uma mata - de grilos e pássaros -, e imagens do documentário Espaço Sagrado (1975), de Geraldo Sarno, sobre um terreiro de candomblé em Cachoeira (BA), aparecem. Nas imagens, uma comunidade candomblecista, vestida com os trajes brancos do culto, caminha por um lugar idílico, e imagens atuais de uma mata fazem fusão com as imagens de arquivo. Depois de ouvir, Xaniqua faz o gesto de assentir com a cabeça: ela entendeu o que deveria procurar.

Figura 10 - Candomblé - Nave (2019); Fonte YouTube

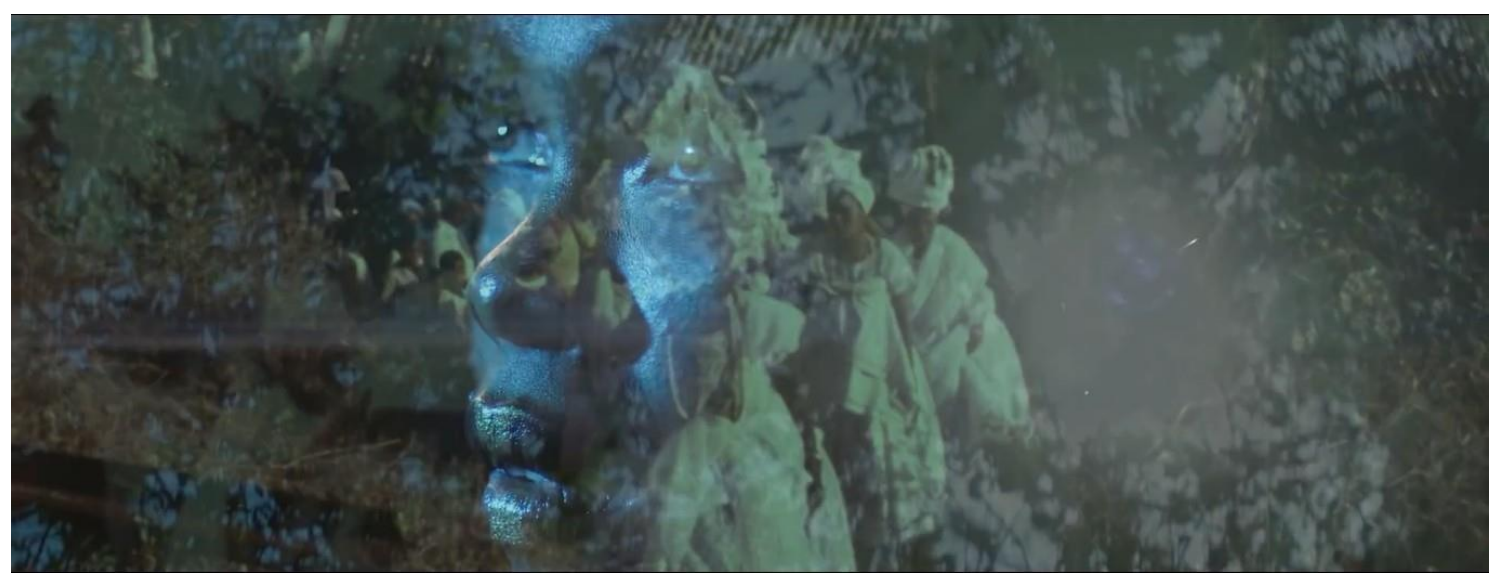

Ela continua sua busca até o momento em que encontra um guaranazeiro e então se transporta para um lugar de mata, cheio de árvores e vegetação. Voltam a aparecer imagens de Espaço Sagrado, do candomblé da região do Recôncavo baiano: a imagem de um lugar de floresta invoca diretamente a sua importância para o rito, afinal os Orixás são forças da natureza; e o guaraná dá pistas sobre a ancestralidade de Xênia, já que ela é oriunda do Recôncavo, região importante de produção da amêndoa. ${ }^{12}$ Xaniqua está feliz e em paz, toca nas plantas e nas árvores, olha tudo ao redor com curiosidade, sentindo e vendo a presença de suas ancestrais.

12 Disponível em: <http://www.seagri.ba.gov.br/noticias/2008/05/12/guaran\%C3\%A1-bons-neg\%C3\%B3ciosno-baixo-sul>. Acesso em: 04/05/2020. 


\section{ALCEU}

ISSN: $2175-7402$

Figura 11 - Guaranazeiro - Nave (2019); Fonte: YouTube

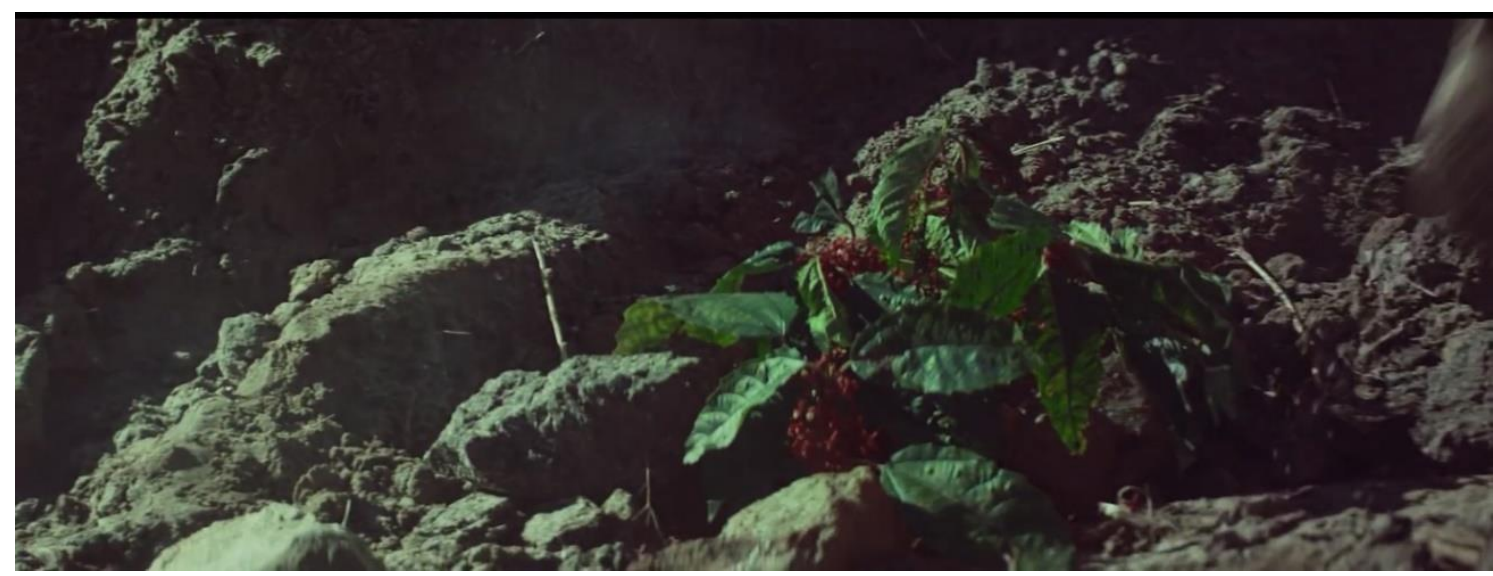

Figura 12 - Natureza utópica - Nave (2019); Fonte: YouTube

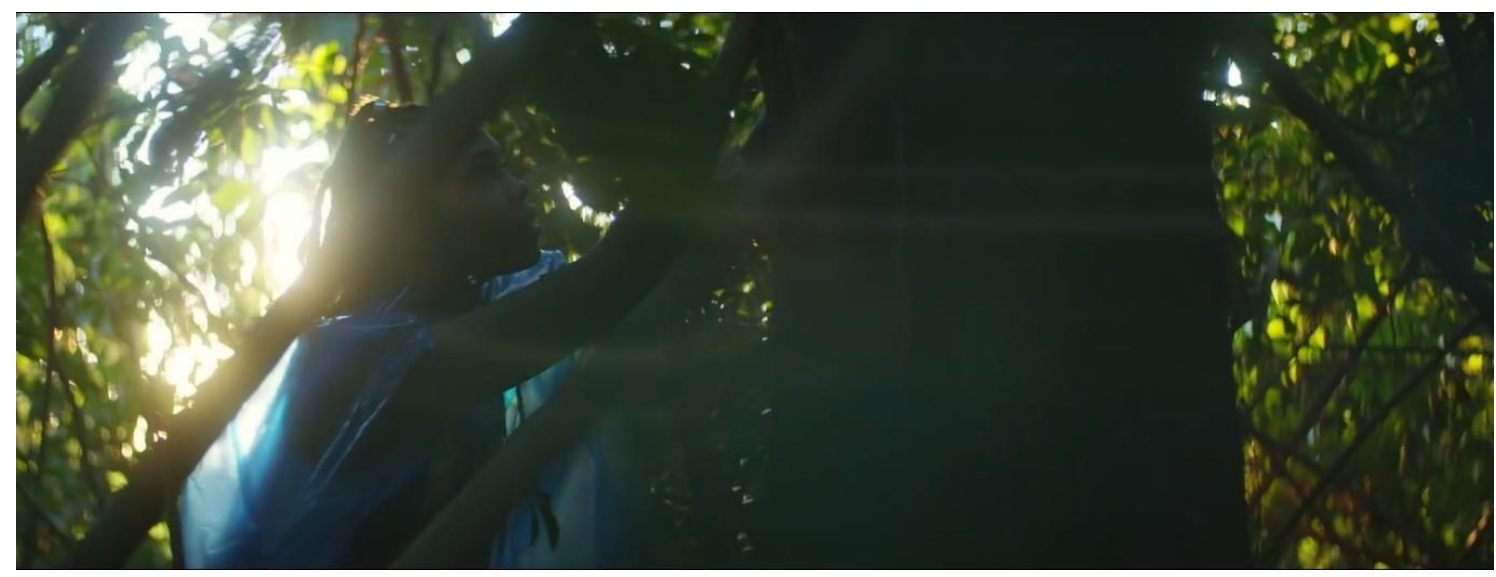

O uso de imagens do passado, a qualidade revisionista da história africana ou a conexão ancestral, que são referenciais importantes na arte afrofuturista, poderiam ser encarados como um paradoxo ou como se esta carregasse a contradição em seu cerne. Essa foi uma observação feita por Mark Dery, mas que Greg Tate (in DERY, 1994, p. 210, tradução minha) logo descontruiu, utilizando a cultura hip-hop como exemplo, quando indagado se de fato o afrofuturismo seria contraditório nesse aspecto:

Não, porque você pode olhar para trás e pensar para frente ao mesmo tempo. A abordagem de tudo no hiphop é sempre com um senso de brincadeira, de modo que até o culto aos antepassados está sujeito à irreverência. Ironicamente, uma das coisas que permitiu à cultura negra sobreviver é sua capacidade de operar de maneira iconoclasta em relação ao passado; as armadilhas da tradição nunca podem atrapalhar a inovação e a improvisação. Você também deve lembrar que a reverência negra pelo passado é uma reverência por um paraíso perdido. Não é um passado que alguém conhece por experiência própria, mas um 
passado colhido de discussões, de livros de estudiosos, como o Dr. Ben Yochanan, que dedicaram suas vidas à pesquisa das glórias científicas das civilizações negras. ${ }^{13}$

Não há irreverência na abordagem de Xênia em relação à ancestralidade, sendo esse apenas um exemplo de referência usado pelo crítico, mas a "tradição" não é um impeditivo para experimentos futuristas e reinvenção de expressões culturais negras. Durante todo o álbum, há a construção de uma sonoridade que mistura atabaques de terreiro com beats e arranjos de um R\&B inovador. Lembra o caráter "desavergonhadamente híbrido" (GILROY, 2001, p. 204) que necessariamente compõe as formas culturais afrodiaspóricas.

Tate (1994) evoca o improviso como forte marcador estético negro, fato defendido também por Gilroy (2001). Há improviso na criação de técnicas vocais, no instrumental ou nas palavras: jazz, embolada, samba de breque, fraseados de blues, rap, scat singing ou os melismas utilizados pelo coral gospel ou no soul, todos têm sua parcela de criação devida ao improviso. Também há improviso na forma de operar os aparatos técnicos que servem a novíssimos gêneros negros oriundos de África e sua diáspora, desde os primeiros toca-discos como instrumentos até a manipulação de softwares e samplers para a construção da narrativa afrossônica na contemporaneidade. O improviso serve tanto ao instrumental como às temáticas para dar vazão a formas criativas de exercer a subjetividade negra num mundo racializado.

Esse desfecho serve para lembrarmos que, apesar de hoje em dia existirem muitas referências de afrofuturismo nos livros de ficção, quadrinhos, na moda e nas artes plásticas, quem primeiro estruturou o que realmente se denomina de arte afrofuturista, segundo Eshun (2003), foi o jazzista Sun Ra. Ele comenta que Ra ajudou a estabelecer essas bases ainda na década de 1950 equilibrando visões de uma África préindustrial e de uma África científica, onde o jazzista criou sua própria cosmologia. O compositor e bandleader da Arkestra dizia que era de Saturno, usava roupas com referências egípcias e espaciais e tocava um jazz avant-garde, uma música experimental que unia referências desde o ragtime, swing e o bebop até o free jazz e o fusion. Também foi um dos primeiros a usar sintetizadores no jazz, fato que corrobora o conteúdo inovador em sua arte.

13 No original: "No, because you can be backward-looking and forwardthinking at the same time. The approach to everything in hip-hop is always with a sense of play, so that even ancestor worship is subject to irreverence. Ironically, one of the things that's allowed black culture to survive is its ability to operate in an iconoclastic way in regard to the past; the trappings of tradition are never allowed to stand in the way of innovation and improvisation. You have to remember, too, that black reverence for the past is a reverence for a paradise lost. It's not a past that anyone knows from experience, but a past gleaned from discussions, from books by scholars like Dr. Ben Yochanan who have dedicated their lives to researching the scientific glories of black civilizations." 
Figura 13 - Cartaz do filme Space is the Place (1974); Fonte: Filmow

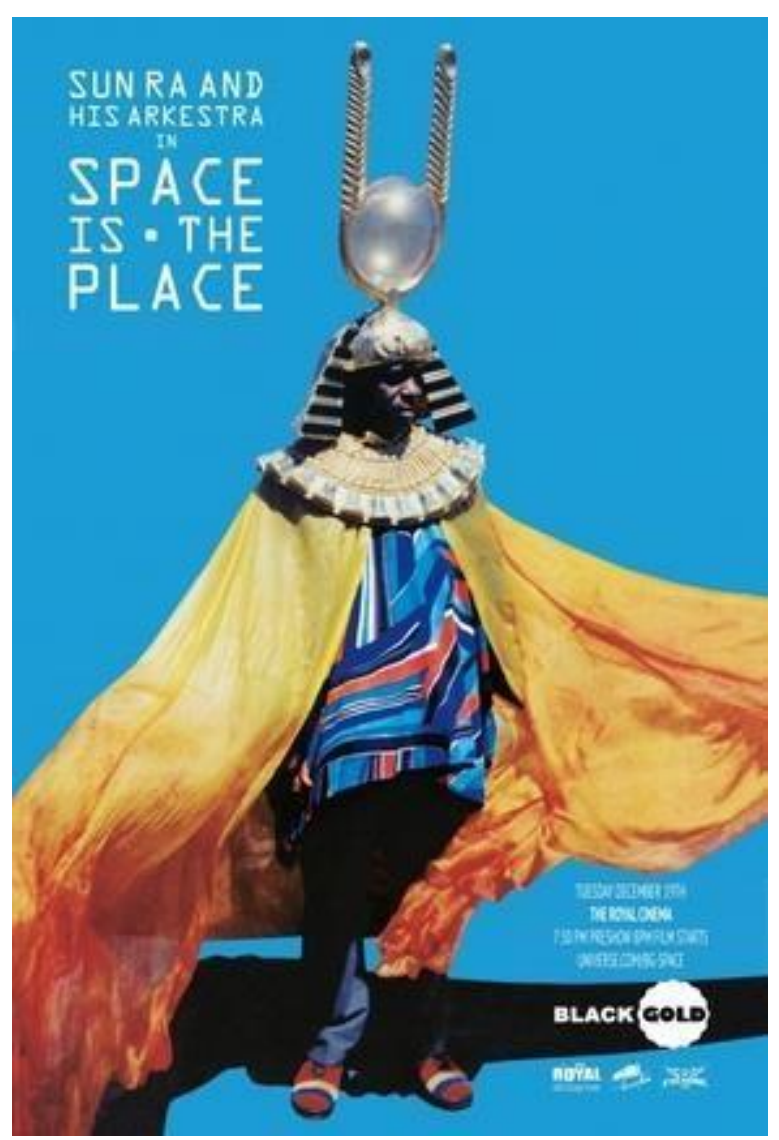

Em seu ensaio Brothers from Another Planet, John Corbett (1994, p. 17-18) faz uma metáfora interessante: ele relaciona a própria característica de inovação da música negra com espaço sideral, loucura e qualidade extraterrestre, enquanto a Terra seria a tradição, algo da ordem do normal, do imutável e, portanto, conservador. Corbett usa a metáfora da exploração, do encontro com o desconhecido, para falar do jazz de Sun Ra, do funk de George Clinton - o cabeça por trás dos grupos Parliament e Funkadelic - e do reggae-dub do jamaicano Lee "Scratch" Perry. Para ele, são exemplos contundentes da inovação dentro da música negra da diáspora que, apesar de independentes entre si tocavam diferentes gêneros, tinham diferentes públicos e relacionavam-se cada um de um jeito com a indústria cultural -, desenvolveram experiências semelhantes nas iconografias espaciais e experimentações sônicas (p. 11). 


\section{ALCEU}

Figura 14 - Capa do disco Mothership Connection (1975) do Parliament. Fonte: Google Imagens

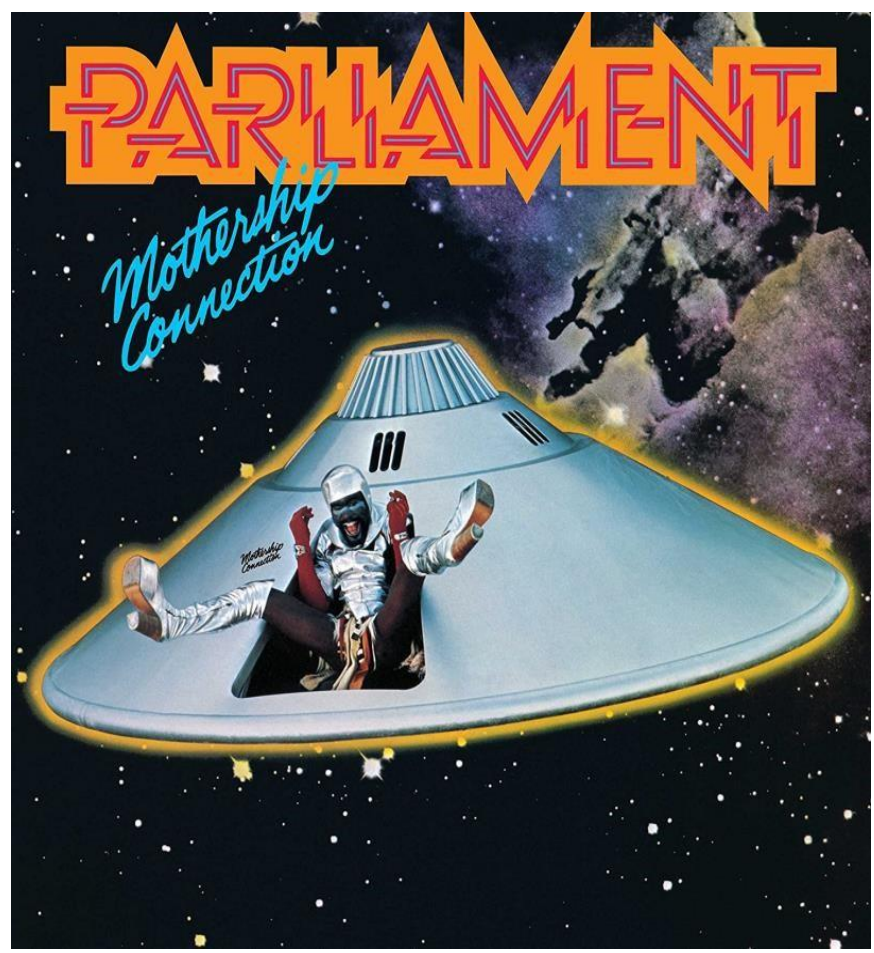

Seguindo as pistas deixadas por Corbett, surge o documentário The Last Angel of History (1995), feito pelo coletivo baseado em Londres Black Audio Film Collective. Para Eshun (2003, p. 295, tradução minha), o "filme-ensaio" dirigido pelo ganês John Akomfrah "continua sendo a exposição mais elaborada sobre a convergência de ideias que é o Afrofuturismo"14. As obras de Ra, Clinton e Perry e suas similaridades são abordadas por meio do personagem Data Thief (Ladrão de Dados), um viajante do tempo em busca de uma tecnologia secreta negra. A partir dessa narrativa, o filme

[...] criou uma rede de ligações entre música, espaço, futurologia e diáspora. Os processos sônicos africanos são aqui reconcebidos como telecomunicações, como componentes distribuídos de um código para uma tecnologia secreta negra que é a chave para o futuro diaspórico. A noção de uma tecnologia secreta negra permite que o afrofuturismo atinja um ponto de aceleração especulativa. ${ }^{15}$

Antes de apresentar o protagonista, o filme começa citando a lenda do bluesman Robert Johnson, que teria vendido sua alma ao diabo, numa encruzilhada no sul dos EUA, em troca de poder tocar o violão como ninguém. Essa história, que ainda é contada à exaustão, deve ser questionada por ser uma narrativa

14 No original: "[...] their essay-film which remains the most elaborate exposition on the convergence of ideas that is Afrofuturism."

15 No original: "[...] created a network of links between music, space, futurology, and diaspora. African sonic processes are here reconceived as telecommunication, as the distributed components of a code to a black secret technology that is the key to diasporic future. The notion of a black secret technology allows Afrofuturism to reach a point of speculative acceleration." 


\section{ALCEU}

ISSN: $2175-7402$

branca colonial, pois a encruzilhada é um lugar de extrema importância em filosofias e cosmologias africanas diversas: como, por exemplo, o papel da encruzilhada para os iorubas e os fons, sendo o lugar primordial de Exu e Legba, Orixá/Vodun poderoso que fora demonizado pelo cristianismo. Por outro lado, a encruzilhada também é lugar importantíssimo para os povos do tronco linguístico Banto, como os ovimbundos, ambundos e bakongo, extremamente influentes na formação da cultura afro-brasileira com suas cosmovisões. Eles também possuem um Nkisi que vive na encruzilhada, chamado Pambu Njila. Em Last Angel o blues é denominado como uma tecnologia negra secreta a partir da qual teriam surgido o jazz, o soul, o hip-hop e o R\&B. Dessa forma, se Data Thief, que está há 200 anos no futuro, conseguir achar essas encruzilhadas e fizer uma escavação arqueológica, ele poderá achar esses "tecno-fósseis" e quebrar o código do segredo e garantir seu futuro.

Figura 15 - Still do Filme The Last Angel of History (1995). Arquivo Pessoal

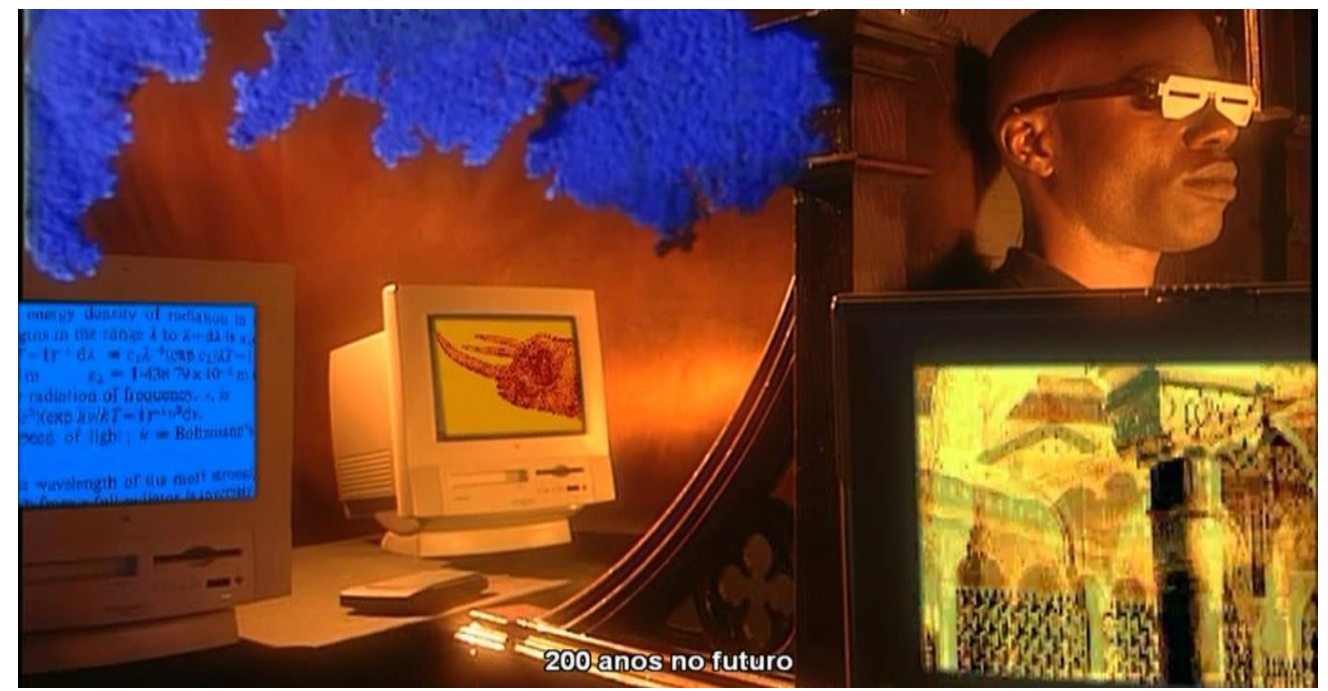

Os tecno-fósseis também poderiam ser as tecnologias do sagrado dos ritos iorubas, ou os búzios e hieróglifos em Nave; e a busca através de uma pesquisa científica por esses artefatos no filme remete à busca de Xaniqua pelo objeto secreto que traria respostas: primeiro ela acha um fóssil de uma planta e, depois, o guaranazeiro. Mais uma vez o cronótopo da encruzilhada aparece numa narrativa negra: uma imbricação de trocas, comunicações e refertilizações da afrodiáspora e, por isso, mais significativa que a ideia de caminho ou estrada. 
Exu é a representação maior da comunicação, dos trânsitos e das trocas, ele é o senhor das encruzilhadas (RUFINO, 2014, p. 60). Sem o orixá não haveria som (SANTOS, 2008, p. 48-49)16, e a música mais uma vez estaria no cerne dessas ligações estereomodernistas (JAJI, 2014) ${ }^{17}$ que narram subjetividades enegrecidas e ensejam afiliações estético-políticas solidárias. O tempo-espaço não linear, porque circular nas culturas negro-africanas, e tão bem representado pelo oriki ${ }^{18}$ desse Orixá, conecta-se com as viagens temporais das narrativas afrofuturistas, afinal “Exu matou um pássaro ontem com uma pedra que só arremessou hoje".

Como separadas no Ocidente, a conjunção de temporalidades - leia-se, passado, presente e futuro - não faria muito sentido para a linha do tempo linear do eurocentrismo. Contrariamente, essa linearidade não faz sentido para muitas culturas africanas, como mostra o arquétipo de Exu. Então, não é de se impressionar que as expressões afrofuturistas contemporâneas façam tantas menções às narrativas de viagem no tempo: ao passado científico africano e à reconexão com a ancestralidade; a voltar no tempo para corrigir algum erro (Sankofa), ou para atuar ali como forma de reparar injustiças históricas; procurar outro planeta ou um futuro livre de racismo, ou preparar um futuro melhor.

Rafael Pinto Ferreira de Queiroz

ORCID: https://orcid.org/0000-0003-1258-5934 Universidade Federal de Pernambuco, Programa de Pós-Graduação em Comunicação, Recife (PE), Brasil Doutor em Comunicação pela UFPE

E-mail: rafaeldequeiroz@gmail.com

\footnotetext{
16 "Toda formulação de som nasce como uma síntese, como um terceiro elemento provocado pela interação ativa de dois tipos de elementos genitores: a mão ou a baqueta percutindo no couro do tambor, a vareta batendo no corpo do agogô, o pêndulo batendo no interior da campainha àjà, a palma batendo no punho etc. Veremos mais adiante que o som da voz humana, a palavra, é igualmente conduzida por Ėșù, nascido da interação dos genitores masculinos e femininos. O som é resultado de uma estrutura dinâmica, em que a aparição do terceiro termo origina movimento. Em todo o sistema, o número três está associado a movimento."

${ }^{17}$ O Stereomodernism é uma ferramenta teórica e metodológica elaborada pela autora Tsitsi Ella Jaji que gira em torno de três principais eixos: solidariedade, modernidade e mídia. Ela defende como a música afrodiaspórica e africana sempre se conectaram e ensejaram processos mútuos de solidariedade panafricanista, lutas políticas anticoloniais, gerando uma releitura de uma modernidade africana construída pelos próprios. A música negra, manifestada em suas mais variáveis mídias, foi o principal motor e meio de comunicação negra transnacional. Para uma aplicação e interpretação em português do estereomodernismo, ver Queiroz (2020).

18 Segundo Reis Neto (2019, p. 71): “A palavra oriki, de origem iorubá, possui muitos sentidos, é a junção de duas palavras orí (cabeça) e kì (louvar), literalmente ela significa "louvar o ori; louvação ao Ori". Entretanto, ela é concebida e comumente utilizada nos cultos afro-diaspóricos no sentido de louvação, evocação, seja do Ori ou de determinada divindade."
} 
Recebido em: 17 de março de 2021.

Aprovado em: 22 de abril de 2021.

\section{Referências}

CORBETT, John. Brothers from Another Planet. In: Extended Play: Sounding off from John Cage to Dr. Funkenstein. Durham: Duke University Press, 1994.

DENISE, Flávia. Xenia França parte em uma jornada de autoconhecimento no videoclipe de "Nave". OPovo, 21/03/2019. Disponível em: <https://orbezero.com.br/xenia-franca-parte-em-uma-jornada-deautoconhecimentono-videoclipe-de-nave/ $\geq$. Acesso em: 04/05/2020.

DERY, Mark. "Black to the future: interviews with Samuel R. Delany, Greg Tate and Tricia Rose". In: Flame Wars: the discourse of cyberculture. Durham: Duke University Press, 1994.

ESHUN, Kodwo. Further considerations of Afrofuturism. CR: The New Centennial Review, v. 3, n. 2, 2003, p. 287-302.

GILROY, Paul. O Atlântico Negro: modernidade e dupla consciência. São Paulo: Ed.

34; Rio de Janeiro: Universidade Candido Mendes, Centro de Estudos Afro-Asiáticos, 2001.

JAJI, Tsitsi Ella. Africa in Stereo: Modernism, Music, and Pan-African Solidarity. New York: Oxford University Press, 2014.

QUEIROZ, Rafael Pinto Ferreira de. Mo pèé iba méta làá b' okán: "Eu invoco vezes três são como uma" - o sistema Exu-Estéreo para ouvir e ver a Diasporadical Trilogia de Blitz The Ambassador. ARTEFILOSOFIA, v. 15, n. 28 , abr. 2020, p. 108-128.

REIS NETO, João Augusto dos. Exu e a descolonização da docência: religiosidade afro-brasileira, cinema e a formação de professores(as). Dissertação (Mestrado - Programa de PósGraduação em Processos Socioeducativos e Práticas Escolares) -Universidade Federal de São João del-Rei, 250 p., 2019.

RUFINO, Luiz. Histórias e saberes de jongueiros. Rio de Janeiro: Multifoco, 2014.

SANTOS, Juana Elbein dos. Os Nagô e a morte. Petrópolis: Vozes, 2008.

THE LAST Angel of History. Direção: John Akomfrah. 45 min, cor, 1996.

WOMACK, Ytasha. Afrofuturism: The world of black sci-fi and fantasy culture. Chicago: Lawrence Hill Books, 2013. 
XENIA França - Nave. Direção: DIABA. 4min34s, cor, 2019. Disponível em:

$\leq$ https://www.youtube.com/watch?v=FoWCoELm57c . Acesso em: 03/07/2020.

\section{Resumo}

O artigo visa analisar o uso do afrofuturismo pela cantora baiana Xênia França, através da análise de seu videoclipe Nave (2019). Tentando entender vários sentidos que emergem do significado do movimento político-estético negro e transnacional a partir de autores como Dery e Tate (1994), Corbett (1994) e Eshun (2003), Womack (2013), procura-se cruzar essas referências como possíveis continuidades e interpretações audiovisuais da canção. Há o entendimento do afrofuturismo enquanto instrumento crítico ao racismo e a percepção de sua manifestação em artes negras como não algo somente da contemporaneidade. Também interessa a sugestão de que a cantora segue uma ligação espaço-temporal tecida pelas encruzilhadas do Atlântico negro, especialmente na música afrodiaspórica.

Palavras-chave: Afrofuturismo. Xênia França. Atlântico Negro. Utopia e distopia. Racismo.

\section{Abstract}

The article aims to analyze the use of afrofuturism by the Bahian singer Xênia França, through the analysis of her video clip Nave (2019). Trying to understand various meanings that emerge from the meaning of the black and transnational political-aesthetic movement from authors such as Dery and Tate (1994), Corbett (1994) and Eshun (2003), Womack (2013), we try to cross these references as possible continuities and audiovisual interpretations of the song. There is the understanding of Afrofuturism as a critical tool to racism and the perception of its manifestation in black arts as not only something of the contemporary. Also there is a concern about the suggestion that the singer follows a spatio-temporal connection woven by the crossroads of the black Atlantic, especially in the African Diaspora music.

Keywords: Afrofuturism. Xênia França. Black Atlantic. Utopian and dystopia. Racism. 


\section{Resumen}

El artículo tiene como objetivo analizar el uso del afrofuturismo por parte de la cantante bahiana Xênia França, a través del análisis de su videoclip Nave (2019). Tratando de comprender los diversos sentidos que surgen del significado del movimiento político-estético negro y transnacional de autores como Dery y Tate (1994), Corbett (1994), Eshun (2003) y Womack (2013), intentamos cruzar estos referencias como posibles continuidades e interpretaciones audiovisuales de la canción. Existe la comprensión del afrofuturismo como un instrumento crítico para el racismo y la percepción de su manifestación en las artes negras como algo no solo de lo contemporáneo. También es interesante la sugerencia de que el cantante sigue una conexión espacio-temporal tejida por la encrucijada del Atlántico negro, especialmente en la música afrodiaspórica.

Palabras clave: Afrofuturismo. Xênia França. Atlántico Negro. Utopía y distopia. Racismo.

Este artigo é publicado em acesso aberto (Open Access) sob a licença Creative Commons Attribution Non-Commercial (CC-BY-NC 4.0), que permite que outros remixem, adaptem e criem a partir do seu trabalho para fins não comerciais, e embora os novos trabalhos tenham de lhe atribuir o devido crédito e não possam ser usados para fins comerciais, os usuários não têm de licenciar esses trabalhos derivados sob os mesmos termos. 